\title{
Values of B and T cells and their subpopulations in peripheral blood of rabbits
}

\author{
BEATA TOKARZ-DEPTUŁA, ${ }^{1,4}$ PAUlinA NiEdŹWIEDZKA-RYSTWEJ, ${ }^{1,4}$ \\ ALICJA TRZECIAK-RYCZEK, ${ }^{1,4}$ ANDRZEJ PĘPIAK, ${ }^{2}$ WIESŁAW DEPTU A $^{3,4}$
}

\author{
Department of Immunology, Faculty of Biology, University of Szczecin, Felczaka 3c, 71-412 Szczecin, Poland, e-mail: kuki001@interia.pl \\ Domestic Animal Clinic, Łubinowa 17, Szczecin, Poland \\ Department of Microbiology, Faculty of Biology, University of Szczecin, Felczaka 3c, 71-412 Szczecin, Poland. \\ Center of Molecular Biology and Biotechnology, Faculty of Biology, University of Szczecin, Szczecin, Poland
}

Keywords rabbit, B and T lymphocytes, reference values

Abstract Determining the reference values for B and T lymphocytes and their subpopulations in rabbits used in Poland for economic and laboratory purposes is not very common. The goal of this study was to evaluate values of chosen B and T cells and their subpopulations in Polish mixed-breed rabbits, taking season of the year and sex of the animals into the consideration. The study was performed with the use of flow cytometry using monoclonal antibodies (mouse anti-rabbit). The study revealed that, both in Polish mixed-breed rabbits and in Polish mixed-breed rabbits with an addition of blood of meat breeds, the season of the year and sex of the animals affect the percentage of B- and T-cells and their subpopulations in peripheral blood. As far as season of the year is concerned, it was shown that it mainly affects CD5+ T cells in mixed-breed rabbits and CD25+ T cells in mixed-breed rabbits with an addition of blood of meat breed, while taking sex of the animals into account, more changes were recorded in females in both groups of rabbits. Due to the fact that this is the first paper on those values in Polish rabbits conducted on a large amount of animals, the values may be treated as reference.

\section{Wartości limfocytów B i T oraz ich subpopulacji we krwi obwodowej u królików}

Słowa kluczowe królik, limfocyty B i T, wartości referencyjne

Streszczenie

Ocena wartości referencyjnych dla limfocytów B i T oraz ich subpopulacji u królików wykorzystywanych w Polsce w celach ekonomicznych i laboratoryjnych jest rzadkością. Celem pracy jest ocena parametrów wybranych limfocytów B i T oraz ich subpopulacji u polskich królików mieszańców z uwzględnieniem pory roku i płci tych zwierząt. Badania wykonano z wykorzystaniem cytometrii przepływowej i przeciwciał monoklonalnych (mouse anti-rabbit). Badania wykazały, że zarówno u królików mieszańców polskich, jak i mieszańców polskich z dolewem krwi ras mięsnych, pora roku i płeć wpływa na kształtowanie badanych parametrów, tj. procentu limfocytów B i T oraz ich subpopulacji. Co się tyczy pory roku wykazano, że zmiany dotyczą głównie limfocytów T CD5+ w przypadku królików mieszańców polskich i limfocytów T CD25+ w przypadku królików mieszańców polskich z dolewem krwi ras mięsnych. Tymczasem w przypadku płci zwierząt, więcej zmian w obu grupach zwierząt 
wykazano u samic. Ze względu na to, że jest to pierwsza praca z tego zakresu i badania dotyczą dużej grupy zwierząt, winny one być traktowane jako wartości referencyjne.

\section{Introduction}

Due to their high economic value (dietetic and flavour values of their meat, and use for fur), and due to their broad use in scientific research and diagnostic procedures, rabbits are generally bred animals. In Poland, for business and laboratory purposes, popular breeds include Polish mixed-breed rabbits and Polish mixed-breed rabbits with addition of blood of meat-breed races usually of Belgian hare. Because of the growing interest in such animals, in order to monitor their health, there is a need for determining the reference values for immunological factors, which are lacking in the literature, for example B and T-cells and their subpopulations. In Poland (Tab. 1) and abroad (Tab. 2), there have been few concerning B and T-cell values in peripheral blood, but not oriented at development of standards. The observations (Tab. 1, 2) also did not account for the impact of physiological properties of rabbits, such as sex and environmental conditions, as season of the year, on the factors analysed, although they were specified in some studies (Tab. 1, 2) when describing the animal material. However, studies on haematological factors of peripheral blood in mixed-breed and pure breed rabbits carried out both in Poland and abroad indicate that these values are significantly affected by the season of the year (Pinna Pintor \& Grassini 1957; Chomicz 1967; Laird et al. 1970; Bortolotti et al. 1989; Jain 1994; Deptuła et al. 1995; Rohilla et al. 2000; Nowaczyk et al. 2004; Chineke et al. 2006; Olayemi \& Nottidge 2007; Archetti et al. 2008; Çetin et al. 2009; Ezema et al. 2009; Jeklova et al. 2009; Poljičak-Milas et al. 2009; Martinec et al. 2012; Yaqub et al. 2013), as well as sex of the animals (Chineke et al. 2006; Çetin et al. 2009; Ezema et al. 2009; Poljičak-Milas et al. 2009; Yaqub et al. 2013). Furthermore, studies regarding haematological image of peripheral blood in Polish mixed-breed rabbits, as well as New Zealand and Angora rabbits, Czech rabbits and mixed-breed rabbits of unspecified origin, also recorded the impact of the age of the animals (Chomicz 1967; Laird et al. 1970; Bortolotti et al. 1989; Deptuła et al. 1995; Chineke et al. 2006; Olayemi \& Nottidge 2007; Archetti et al. 2008; Jeklova et al. 2009; Yaqub et al. 2013) and their race (Jain 1994; Rohilla et al. 2000; Chineke et al. 2006; Martinec et al. 2012; Yaqub et al. 2013).

In studies on rabbits lymphocytes it was shown that in this species B lymphocytes are exceptional due to their complexity of cell surface markers and surprisingly their proportion versus $T$ cells may be different then in other species (Sobolovič et al. 1977). Due to this fact, the most reliable method of evaluating this subpopulation of cells is based on CD19 marker the most pivotal receptor on those cells.

As the subpopulation of $\mathrm{T}$ cells is more divert, it is also recommended to evaluate the markers that are most basic and identifiable, such as CD4+, CD8+ and CD25+.

The aim of the present work is to develop reference values (standards) for B-cells with CD19+ receptor, and T-cells with CD5+ receptor, and their subpopulations, i.e. T-cells with receptors CD4+, CD8+ and CD25+ in peripheral blood in Polish mixed breed rabbits and Polish mixed-breed rabbits with addition of meat-breed races, considering the impact of the season of the year and sex of the animals on such values. 


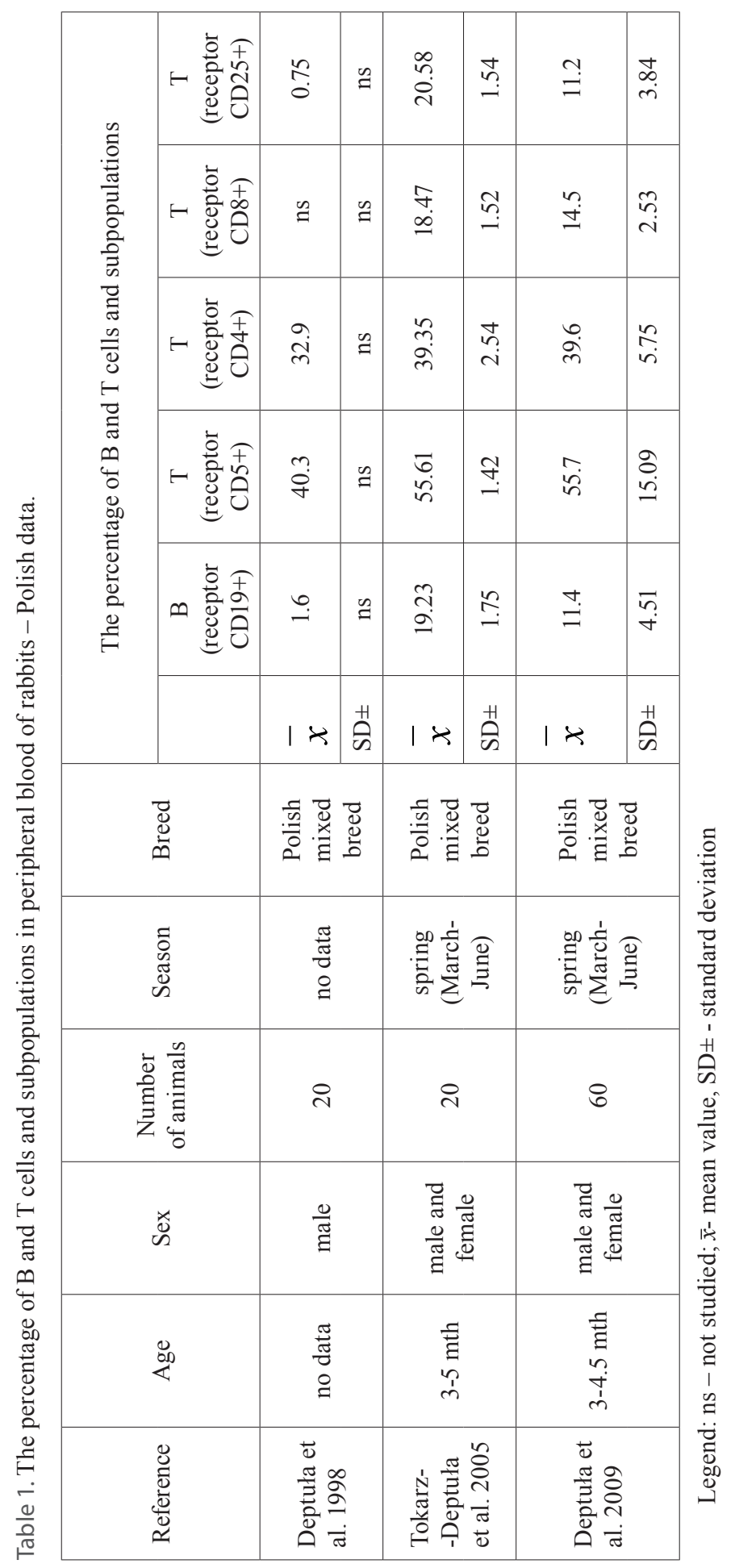




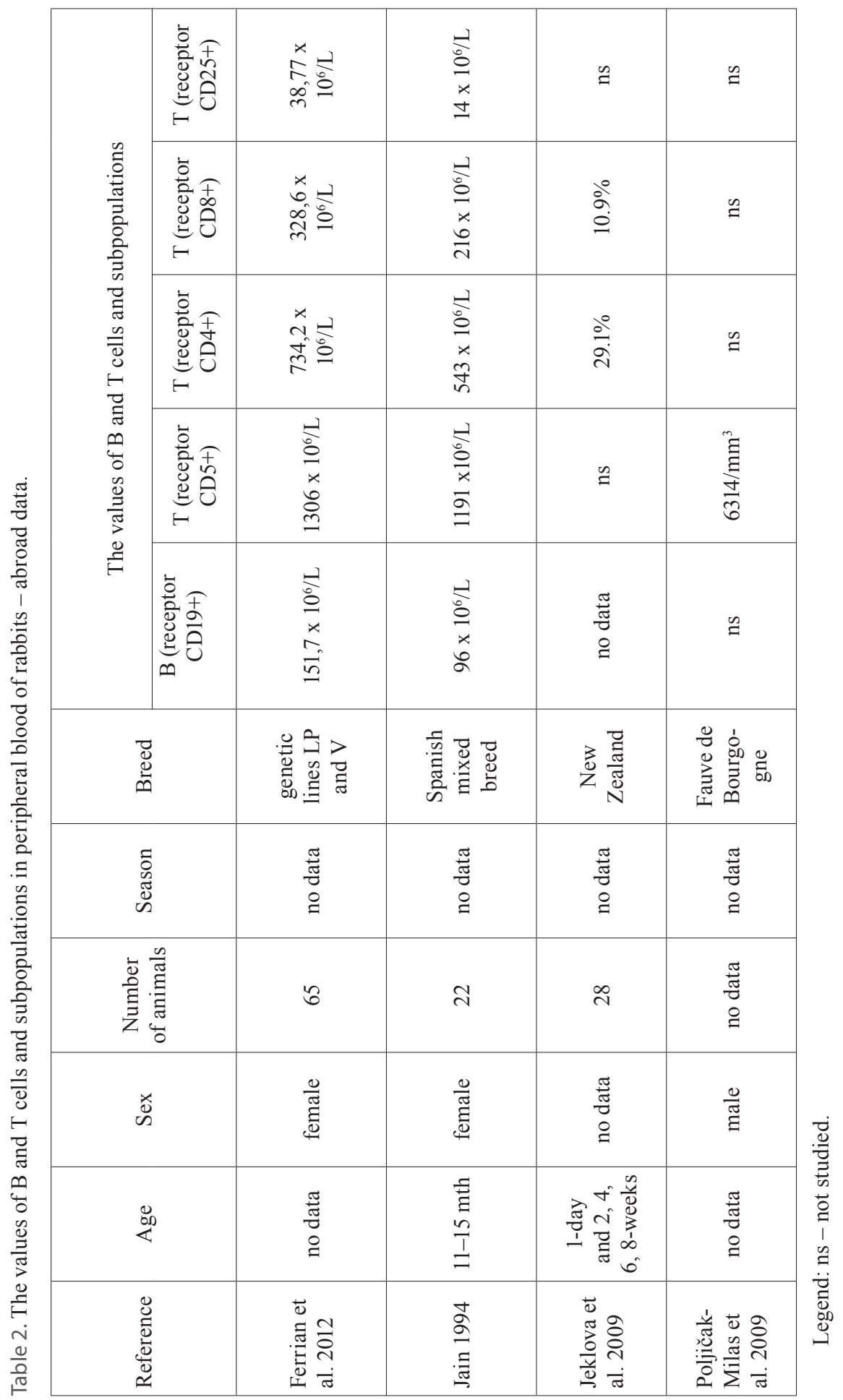




\section{Material and Methods}

The study involved 200 Polish mixed-breed rabbits and 200 Polish mixed-breed rabbits with an addition of blood of meat breeds, originating from a licensed farm, remaining under continuous veterinary and zoo-technical supervision (Anon 1987), weighing 3.2-4.2 kg, aged 6-8 months, females and males, in four seasons of the year: spring, summer, autumn, and winter. During the experiment, the animals remained at the vivarium, where zoo-technical parameters were in line with the recommended Polish standards developed in line with the European Union Directive as regards temperature and humidity, as well as lighting and size of cages for animals (Anon 2006). After transportation to the Department vivarium, the animals were provided with a two-week adaptation period. The animals were fed with complete feed_(Królik 16, Motycz, Poland), at volume of $0.15-0.20 \mathrm{~kg} / \mathrm{day}$, and had unlimited access to water.

The study was carried out twice (every seven days) in four seasons (spring, summer, autumn, winter) for both animal groups. Blood for tests was drawn by establishing a port from marginal vein of the ear, at 24-hour intervals, for three consecutive days, at 08:00 h, namely at hours 0,24 and $48 \mathrm{~h}$ from commencement of the study. In blood of rabbits, the percentage of B-cells with CD19+ receptor, and T-cells with CD5+ receptor, as well as their subpopulations - T-cells with receptors CD4+, CD8+ and CD25+ was determined according to the method described by Deptuła et al. (1998), corresponding to a particular cell pool (cytometrically calculated cells total was 10.000 , which was determined as $100 \%$ ), using monoclonal antibodies (mouse anti-rabbit) (Serotec, USA). The analysed samples were incubated for 45 minutes in ice, rinsed three times with Cell Wash (BD Biosciences, USA) by centrifugation at $200 \times \mathrm{g}$. To this prepared cellular sediment, $10 \mu \mathrm{l}$ of rabbit antibodies were added marked against mouse IgG with fluorescein isothiocyanate (FITC). After triple repetition of the rinsing procedure in Cell Wash, $2000 \mu 1$ of lysing solution was added to samples to eliminate erythrocytes (BD FACS Lysing Solution, BD Biosciences, USA). After ten minutes of incubation in the dark, at room temperature, measurement was performed on FACScan flow cytometer by Becton Dickinson (USA) using FACSDiva software.

The results of the study on B- and T-cells and their subpopulations in percentage, as obtained from three blood draws from each rabbit (at 0, 24, $48 \mathrm{~h}$ ), performed twice at the interval of seven days in each season of the year and subjected to statistical analysis using Student's t-test at $\mathrm{p}=0.05$, are presented as average values and standard deviations in Tables 3 and 4 . 


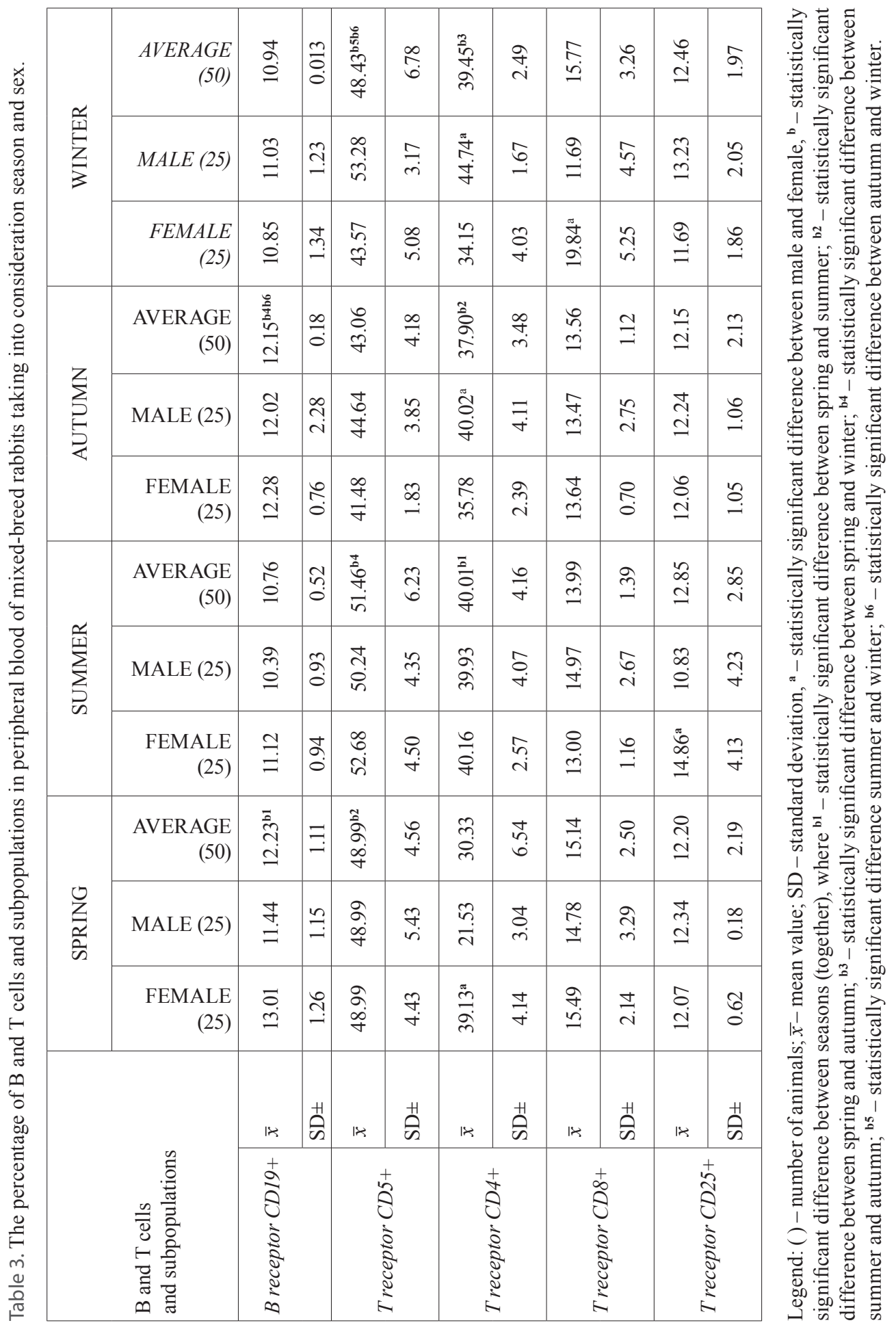




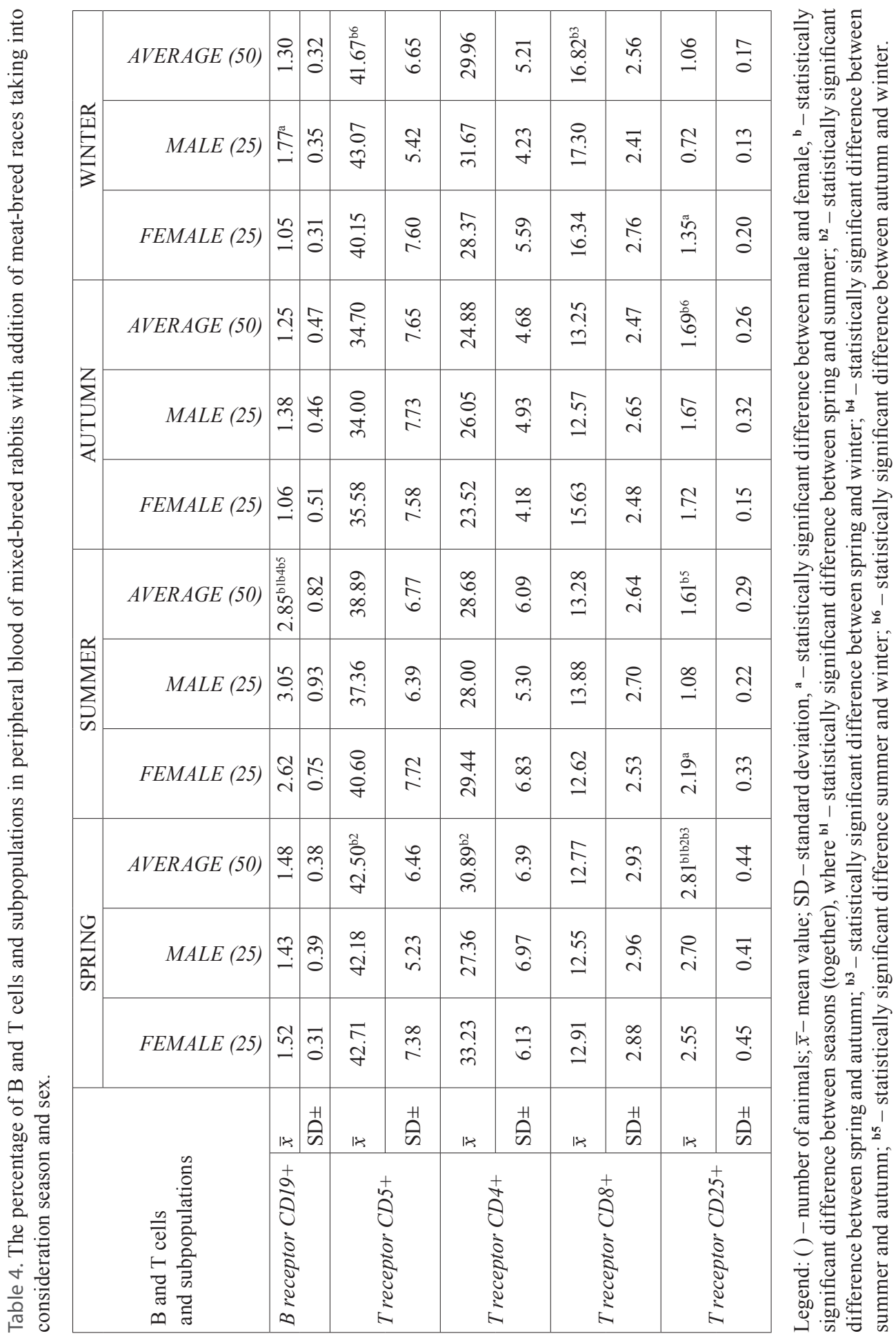




\section{Results}

\section{Results in the area of B-and T-cells and their subpopulations in Polish mixed-breed rabbits}

The values for CD19+ B-cells in Polish mixed-breed rabbits remain within the range from 10.76-12.23\%, for CD5+ T-cells: 43.06-51.46\%, CD4+ T-cells: 30.33-40.01\%, CD8+ T-cells: 13.56-15.77\%, whereas for CD25+ T-cells: $12.15-12.85 \%$ (Tab. 3 ).

The analysis of the impact of the seasons on the analysed elements of blood in rabbits without considering the sex (average for females and males) (Tab. 3) revealed that the highest values for CD19+ B-cells were obtained in spring and autumn, while the lowest in summer and winter; for CD5+ T-cells the highest values were recorded in summer, spring and winter, while the lowest in autumn, while for CD4+ T-cells the highest values were observed in summer, autumn and winter, while the lowest in spring. Highest values for CD8+ T-cells were obtained in spring and winter, and lowest in summer and autumn, while for CD25+ T-cells the values remained at a similar level throughout the year. Furthermore, statistical analysis revealed significant differences between the values obtained in spring and summer for CD19+ B-cells and CD4+ T-cells; between spring and autumn - to CD5+ T-cells and CD4+ T-cells, and between spring and winter - for CD4+ T-cells. The differences were also found between summer and autumn in the percentage of CD19+ B-cells and CD5+ T-cells, while differences between summer and winter - exclusively in the area of CD5+ T-cells, whereas differences between autumn and winter - as regards CD19+ B-cells and CD5+ T-cells.

In turn, the assessment regarding the impact of sex of the animals on the percentage of Band T-cells and their subpopulations in peripheral blood of Polish mixed-breed rabbits (Table 3) in particular seasons of the year (spring, summer, autumn, winter) evidenced higher values in females as compared to males, as for females in spring they referred to CD4+ T-cells, in summer to CD25+ T-cells, and winter for CD8+ T-cells, while in males analogical increase in the values analysed was recorded in autumn and winter, and exclusively for CD4+ T-cells.

\section{Results in the area of B-and T-cells and their subpopulations in Polish mixed-breed rabbits with addition of blood of meat breeds}

The values for CD19+ B-cells in Polish mixed-breed rabbits with an addition of blood remain within the range from 1.05 to $3.05 \%$, for CD5+ T-cells: $34.00-43.07 \% \%$, CD4+ T-cells: 23.52-33.23\%, CD8+ T-cells: 12.55-17.30\%, whereas for CD25+ T-cells: 0.72-2.81\% (Table 4).

The analysis of the impact of the seasons on the analysed elements of blood in rabbits without considering the sex (average for females and males) (Table 4) revealed that the highest values for CD19+ B-cells were obtained in summer, while lowest in spring, autumn and winter; for CD5+ T-cells highest were in spring and winter, and lowest in summer and autumn, while for CD4+ T-cells the highest values were observed in spring, summer and winter, while the lowest in autumn. For CD8+ T-cells highest values were obtained in winter, lowest in spring, summer and autumn, whereas for CD25+ T-cells the highest values were recorded in spring, while the lowest in summer, autumn and winter. Furthermore, statistical analysis revealed significant differences between the values obtained in spring and summer for CD19+ B-cells and CD25+ T-cells; between spring and autumn - to CD5+ T-cells, CD4+ T-cells and CD25+ T-cells; and between spring and winter for CD8+ and CD25+ T-cells. Also significant differences between summer and autumn were 
recorded for CD19+ B-cells, and differences between summer and winter - in the area of CD19+ B-cells and CD25+ T-cells, whereas differences between autumn and winter - as regards CD5+ and CD25+ T-cells.

When analysing the impact of sex on the discussed factors in peripheral blood in particular seasons of the year (spring, summer, autumn, winter) (Table 4), significant increases were revealed in females as compared to males in summer and winter for CD25+ T-cells. Analogical increase in the values analysed was also recorded in males as compared to females in winter, and exclusively for CD19+ B-cells.

When analysing the results obtained in the area of percentage of CD19+ B-cells and CD5+ T-cells, as well as their subpopulations (CD4+ T-cells, CD8+ T-cells and CD25+ T-cells), it must be stated that the values obtained in Polish mixed-breed rabbits, and in Polish mixed-breed rabbits with an addition of meat breed races, they can be compared to three studies by Polish authors (Table 1) on Polish mixed-breed rabbits and to one foreign study on New Zealand rabbits (Jeklova et al. 2009, but only as regards CD4+ and CD8+ T-cells, as other results of foreign studies (Table 2) regarding such cells, carried out on Fauve de Bourgogne and Spanish mixed breed, have been presented in different units, which prevents their comparison with the present results.

\section{Discussion}

Results for Polish mixed-breed rabbits for CD19+ B-cells, as well as CD25+ T-cells (Tab. 3), are similar to the results obtained previously in Polish mixed-breed rabbits (Tokarz-Deptuła \& Deptuła 2005 in Tab. 1), although much lower values (Deptuła et al. 1998 in Tab. 1) and higher values (Deptuła et al. 2009 in Tab. 1) were also recorded (Tab. 3). However, as regards CD5+, CD4+ and CD8+ T-cells, the present results actually correlate with the results obtained in previous studies on Polish mixed-breed rabbits (Deptuła et al. 1998; Tokarz-Deptuła \& Deptuła 2005; Deptuła et al. 2009 in Tab. 1) and New Zealand rabbits, as far as CD4+ and CD8+ is concerned (Jeklova et al. 2009 in Tab. 2), but no fluctuations were determined in them as recorded for CD19+ B-cells and CD25+ T-cells.

When analysing the changes regarding the impact of the seasons of the year on B- and T-cell values and their subpopulations, highest values in all the analysed peripheral blood factors were most frequently recorded in autumn and summer, while the lowest in winter and spring. Furthermore, season most significantly affects the values of CD5+ T-cells, as for this parameter, four significant changes were recorded; as well as CD19+ B-cells and CD4+ T-cells, where three significant changes were recorded for each of these cells (Tab. 3). The impact of the season on such peripheral blood factors has not been confirmed in the studies by other authors, and the present study is the first in the literature in that filed. Moreover, in the case of studies on haematological factors in Polish mixed-breed rabbits, it was determined that the season of the year to a small degree affects the analysed peripheral blood factors, as it only affects the number of monocytes, lymphocytes and haemoglobin concentration (Tokarz-Deptuła et al. 2014).

In turn, the assessment regarding the impact of sex of the animals on the percentage of B- and T-cells and their subpopulations in peripheral blood of Polish mixed breed rabbits (Tab. 3) evidenced that more significant values are recorded in the factors analysed in females rather than males, as for females they were recorded in spring for CD4+ T-cells, summer for CD25+ T-cells, and winter for CD8+ T-cells, while in males they were only recorded in autumn and winter and exclusively for CD4+ T-cells, which points to the fact that sex most intensely affects CD4+ T-cells. When referring such facts to haematological studies in Polish mixed-breed rabbits, it was 
evidenced (Tokarz-Deptuła et al. 2014) that sex is of importance principally in autumn and winter for the number of lymphocytes and thrombocytes in males, and monocytes in females.

Results for Polish mixed-breed rabbits with an addition of meat breed receptor CD19+ B-cells and CD25+ T-cells (Tab. 4) are similar to values obtained previously in typical Polish mixed-breed rabbits (Deptuła et al. 1998 in Tab. 1), although also much higher values were recorded in prior studies (Tokarz-Deptuła \& Deptuła 2005; Deptuła et al. 2009 in Tab. 1). However, the results regarding the percentage of CD5+, CD4+ and CD8+ T-cells (Tab. 4) confirm the results obtained for such cells in typical Polish mixed-breed rabbits (Deptuła et al. 1998; Tokarz-Deptuła \& Deptuła 2005; Deptuła et al. 2009 in Tab. 1) and New Zealand rabbits (Jeklova et al. 2009 in Tab. 2).

When analysing the changes regarding the impact of the seasons of the year on B-and T-cell values and their subpopulations, the highest values in all the analysed peripheral blood factors were most frequently recorded in spring and winter, while the lowest in autumn. Moreover, the season of the year most significantly affects the values of CD25+ T-cells, as for this parameter, five significant changes were recorded; as well as CD19+ B-cells, where three significant changes were recorded, and to a lesser extent CD5+ T-cells (two changes), as well as CD4+ and CD8+ T-cells (one change each) (Tab. 4). In turn, studies on the impact of the season on haematological factors in Polish mixed-breed rabbits with an addition of meat breeds evidenced (Tokarz-Deptuła et al. 2014) that the season of the year intensely affects such factors, and it refers to the volume of basophils, eosinophils, monocytes, and to a lesser extent to erythrocytes, lymphocytes, haemoglobin concentration and the volume of neutrophils.

When analysing the impact of sex on the factors analysed (Tab. 4), it was evidenced that the impact is different in females and males, as in females more significant values were recorded, falling in summer and winter, while in males only in winter, and these referred to CD25+ T-cells in females, while to CD19+ B-cells in males. Whereas haematological studies on Polish mixed-breed rabbits with an addition of meat breeds evidenced (Tokarz-Deptuła et al. 2014) that the sex influences the values in summer, autumn and winter as regards the volume of eosinophils and neutrophils in females, while neutrophils and thrombocytes in males.

Due to the fact that the study was carried out on a large animal material (400 rabbits), and the fact that in the case of Polish mixed-breed rabbits the results correlated to the values obtained in prior studies also on mixed-breed rabbits (Deptuła et al. 1998; Tokarz-Deptuła \& Deptuła 2005; Deptuła et al. 2009) and on New Zealand rabbits (Jeklova et al. 2007), the values obtained for B- and T-cells and their subpopulations in peripheral blood of Polish mixed-breed rabbits should be treated as reference values and are as follows: for CD19+ B-cells: 10.76-12.23\%, for CD5+ T-cells: 43.06-51.46\%, CD4+ T-cells: 30.33-40.01\%, CD8+ T-cells: $13.56-15.77 \%$, and for CD25+ T-cells: $12.15-12.85 \%$; whereas the values of such factors in Polish mixed-breed rabbits with an addition of blood of meat breed races are as follows: CD19+ B-cells: 1.05-3.05\%, CD5+ T-cells: 34.00-43.07\%, CD4+ T-cells: 23.52-33.23\%, CD8+ T-cells: $12.55-17.30 \%$, whereas for CD25+ T-cells: $0.72-2.81 \%$ (Tab. 4), so their values are slightly different, in particular as regards CD25+ T-cells, CD19+ B-cells and CD5+ T-cells. The study also revealed that, both in Polish mixed-breed rabbits and in Polish mixed-breed rabbits with an addition of blood of meat breeds, the season of the year and sex of the animals affect the percentage of B- and T-cells and their subpopulations in peripheral blood.

Analyzing the impact of the season of the year in Polish mixed-breed rabbits, it was evidenced that it principally affects the values of CD5+ T-cells, achieving the highest values in autumn and summer, while in the case of Polish mixed-breed rabbits with an addition of blood of meat breeds it was determined that it principally affects the values of CD25+ T-cells, yielding the highest values in sprint and winter. 
In turn as regards the sex of the animals, more changes were recorded in females - both in mixed-breed rabbits and mixed-breed rabbits with an addition of blood of meat breeds, whereas in females of Polish mixed-breed rabbits principally within CD4+ T-cells in spring, summer and winter, while in females of Polish mixed-breed rabbits with an addition of blood of meat breeds principally in CD25+ T-cells in summer and winter. In males, however, such changes referred to CD4+ T-cells (Polish mixed-breed rabbits) and CD19+ B-cells (Polish mixed-breed rabbits with an addition of blood of meat breeds) in autumn and winter.

\section{References}

Anon. 1987. Information and training materials of the Laboratory Animals Section, General Assembly of the Association of Agricultural Engineers and Technicians, 187, pp. 26-77.

Anon. 2006. Regulation of the Minister of Agriculture and Rural Development of 10.03.2006 on detailed conditions for maintenance of laboratory animals in experimental units, breeding units and suppliers (Polish Journal of Laws of 2006, No. 50, item 368).

Archetti I., Tittarelli C., Ceriolo M., Brivio R., Grilli G., Lavazza A. 2008. Serum chemistry and hematology values in commercial rabbits: preliminary data from industrial farms in Northern Italy. Proceed $9^{\text {th }}$ World Rabbit Congress, Verona, Italy, pp. 1147-1151.

Bortolotti A., Castelli D., Bonnatti E. 1989. Hematology and serum chemistry values of adult, pregnant and newborn new Zealand rabbits (Oryctolagus cuniculus). Lab. Anim. Sci., 39: 437-439.

Chomicz L. 1967. Pathological changes of blood depending on sex and age of rabbits experimentally infected with sheep strain of Strongyloides papillosus. Acta Parasitol. Pol., 14: 251-263.

Chineke C.A., Ologun A.G., Ikeobi C.O.N. 2006. Haematological parameters in rabbits breeds and crosses in humid tropics. Pak. J. Biol. Sci., 9: 2102-2106.

Çetin N., Bekyürek T., Çetin E. 2009. Effects of sex, pregnancy and season on some haematological and biochemical blood values in angora rabbits. Scand. J. Lab. Anim. Sci., 36: 155-162.

Deptuła W., Górecka-Odkała D., Tokarz-Deptuła B. 1995. Dynamics of selected immunological parameters in 3-5 months old rabbits. Med. Weter., 51: 552-554.

Deptuła W., Kostrzewa A., Stosik M., Tokarz-Deptuła B., Wiktorowicz K. 1998. Subpopulations of peripheral blood lymphocytes in rabbits. Nowiny Lek., 67: 377-382.

Deptuła W., Niedźwiedzka-Rystwej P., Śliwa J., Tokarz-Deptuła B., Hukowska-Szematowicz B., Pawlikowska M. 2009. Specific immunity in healthy rabbits. Centr. Europ. J. Immunol., 34: 18-19.

Ezema W.S., Omeke B.C.O., Eze J.I., Nwanta J.A. 2009. Studies on the sexual behaviour, haematology and spermatogenesis of male rabbits infected with Trypanosoma brucei brucei. Comp. Clin. Pathol., 18: $63-68$.

Ferrian S., Guerrero I., Blas E., García-Diego F., Viana D., Pascual J.J., Corpa J.M. 2012. How selection for reproduction or foundation for longevity could have affected blood lymphocyte populations of rabbit does under conventional and heat stress conditions. Vet. Immunol. Immunopath., 150: 53-60.

Jain J.M. 1994. Comparative hematologic features of some avian and mammalian species. In: Essentials of veterinary hematology. N.C. Jain (ed.). Philadelphia, Lea and Febiger, pp. 367-376.

Jeklova E., Leva L., Faldyna M. 2007. Lymphoid organ development in rabbits: major lymphocyte subsets. Develop. Comp. Immunol., 31: 632-644.

Jeklova E., Leva L., Knotogova P., Faldyna M. 2009. Age-related changes in selected haematology parameters in rabbits. Res. Vet. Sci., 86: 525-528. 
Laird C.W., Fox R.R., Mitchell B.P., Blau E.M., Schultz H.S. 1970. Effect of strain and age on some hematological parameters in the rabbit. Am. J. Physiol., 218: 1613-1617.

Martinec M., Härtlova H., Chodová D., Tůmová E., Fučiková A. 2012. Selected haematological and biochemical indicators in different breeds of rabbits. Acta Vet. Brno, 81: 371-375.

Nowaczyk P., Deptuła W., Tokarz-Deptuła B., Ossowski A., Suproń M. 2004. Dynamics of chosen immune-haematological parameters in rabbits in annual cycle. Centaur Lubuski, 61: 6-10.

Olayemi F.O., Nottidge H.O. 2007. Effect on the blood profiles of the New Zealand rabbit in Nigeria. Afr. J. Biomed. Res., 10: 73-76.

Pinna Pintor P., Grassini V. 1957. Individual and seasonal spontaneous variations of haematological values in normal male rabbits. Statistical survey. Acta Haematol. 17: 122-128.

Poljičak-Milas N., Kardum-Skelin I., Vudan M., Marenjak T.S., Ballarin-Perharić A., Milas Z. 2009. Blood cell count analyses and erythrocyte morphometry in New Zealand white rabbits. Veterinarski Arhiv, 79: 561-571.

Rohilla P.P., Bujaubauah K.M., Singh G., Kumar M. 2000. Haematological and biochemical studies on pure and crossbred rabbits. Ind. J. Anim. Sci., 70: 60-62.

Sabolovič N., Sabolovič D., Guilman A.M. 1977. T and B cell surface markers on rabbit lymphocytes. Immunol., 32: 581-590.

Tokarz-Deptuła B., Deptuła W. 2005. Values of selected immune and haematological parameters in healthy rabbits. Pol. J. Vet. Sci., 8: 107-112.

Tokarz-Deptuła B., Niedźwiedzka-Rystwej P., Adamiak M., Hukowska-Szematowicz B., Trzeciak-Ryczek A., Deptuła W. 2014. Values of white and red blood cell parameters in Polish mixed breed rabbits in the annual cycle. Pol. J. Vet. Sci., 17: 643-655.

Yaqub L.S., Kawu M.U., Ayo J.O. 2013. Influence of reproductive cycle, sex, age and season on haematologic parameters in domestic animals: a review. J. Cell Anim. Biol., 7: 37-43.

Cite as: Tokarz-Deptuła B., Niedźwiedzka-Rystwej P., Trzeciak-Ryczek A., Pępiak A., Deptuła W. 2016. Values of B and T cells and their subpopulations in peripheral blood of rabbits. Acta Biologica, 23: 127-138. DOI: 10.18276/ab.2016.23-11. 